\author{
SERIES 'RESPIRATORY EFFECTS OF AIR POLLUTION' \\ Edited by P. Paoletti and $U$. Costabel
}

\title{
Long-term canine exposure studies with ambient air pollutants
}

\author{
J. Heyder, S. Takenaka
}

Long-term canine exposure studies with ambient air pollutants. J. Heyder, S. Takenaka. (C)ERS Journals Ltd 1996.

ABSTRACT: Dogs are often the species of choice as an experimental model for the study of pulmonary responses to long-term exposure to air pollutants in chambers simulating environmental or occupational exposure in man. Their lungs bear a reasonable resemblance to human lungs, they are large enough to allow serial measurements of pulmonary responses, and they live long enough to ensure that findings are not confounded by aging.

Several long-term canine exposure studies with ambient air pollutants have been performed since 1957: seven studies with gaseous and particulate sulphur (IV); three studies with nitrogen oxides; three studies with ozone; two studies with acidic particles; three studies with mixtures of sulphurous pollutants that might have resembled the 1952 London smog; and one study in which raw and ultra violet (UV)-irradiated motor vehicle exhaust and sulphurous pollutants were used. The findings support the hypothesis that long-term exposure to air pollutants at ambient levels might cause bronchitic lesions (sulphur oxide), emphysematous lesions (nitrogen dioxide) or fibrotic lesions (ozone). None of the studies showed an indication of synergistic effects.

To improve our understanding of pulmonary responses initiated by the inhalation of pollutants over long periods of time, new concepts are needed. Investigators should consider studies with canine models of cardiopulmonary diseases, the application of novel immunological and molecular biology techniques, the phenomena of tolerance and adaptation to inhaled air pollution, and exposure atmospheres with increasing complexity, including fine and ultrafine particles.

Eur Respir Dis., 1996, 9, 571-584.

There is increasing evidence of an association between air pollution and the exacerbation and development of respiratory diseases. However, more data on exposureresponse relationships and underlying mechanisms are needed to test the hypothesis of causality. The collection of these data requires integrated lines of investigation: long-term animal studies and in vitro studies with well-defined exposure atmospheres composed of single pollutants or mixtures of pollutants. These studies must be complemented by short-term human exposure studies. Together, these research efforts must address the following questions: 1) Which pollutants or combinations of pollutants should be considered pneumotoxins? 2) What dose of these pollutants should be considered harmful? 3) Which individuals are at risk? and 4) Is it feasible to extrapolate pulmonary responses to pollutants observed in laboratory animals to human lungs?

Previously published reviews of this series

1. Sandström T. Respiratory effects of air pollutants: experimental studies in humans. Eur Respir J 1995; 8: 976-995.

2. Chitano P, Hosselet JJ, Mapp CE, Fabbri LM. Effect of oxidant air pollutants on the respiratory system: insights from experimental animal research. Eur Respir J 1995; 8: 1357-1371.
GSF-Forschungszentrum für Umwelt und Gesundheit (National Research Center for Environment and Health), Institute for Inhalation Biology, Oberschleissheim, Germany.

Correspondence: J. Heyder

GSF-Institut für Inhalationsbiologie

D-85758 Oberschleissheim

Germany

Keywords: Air pollution

dog

health effects

long-term exposure

lung

Received: December 121995

Accepted December 131995
It is, therefore, very important to select the appropriate species for studies with laboratory animals. Progressive pulmonary responses observed in these animals should mimic the slowly developing, harmful effects to low levels of air pollution seen in humans.

Frequently, the species used are small (e.g. rat, mouse, hamster, guinea-pig, rabbit); especially for cross-sectional studies involving large groups of animals exposed to different levels of pollutants [1-13]. However, these animals are too small to be used in longitudinal studies, in which pulmonary responses of individuals during longterm exposure are of interest in order to simulate environmental or occupational long-term exposure of humans.

Monkeys and cats have been used to study morphological alterations initiated by inhaled pollutants $[3,4$, 14-16]. Although monkeys are closer to humans than cats, they are difficult to handle and long-term studies are costly and labour intensive. Cats can also be difficult to handle. Therefore, dogs are often the species of choice for long-term exposure studies with air pollutants. They are easy to handle, their lungs bear a reasonable resemblance to human lungs, they are large enough to allow serial measurements of pulmonary responses over the course of a long-term exposure, and they live long enough 
to ensure that findings are not confounded by aging of the animals.

There is now sufficient evidence from long-term animal studies to conclude that exposure to high levels of sulphur dioxide results in bronchitic lesions [17-21], high levels of nitrogen dioxide produce emphysematous lesions, and ozone induces fibrotic lesions [22]. To better understand the pulmonary responses to these and other air pollutants, especially when present at lower, more ambient levels, a number of long-term studies have been conducted using dogs exposed in chambers [23-52]. The specific pollutants under investigation have been ozone, nitrogen oxides, gaseous and particulate sulphur(IV) $\mathrm{S}(\mathrm{IV})$, acidic particles, and motor vehicle exhaust. This review is focused on the results from these studies and is part of the series "Respiratory Effects of Air Pollution" $[22,53,54]$. Response of canine lungs to inhaled cigarette smoke [55-59], or inhaled radionuclides [59-61] are not considered in this review.

Sources, ambient levels, air quality standards and respiratory responses to the pollutants listed above are discussed and summarized in a number of documents [53, 62-69].

\section{Characteristics of the canine respiratory system}

Among canine strains, the beagle is the most widelyused for respiratory toxicology studies. The structural and functional characteristics of its respiratory system are well-documented, with the current database dating back to 1970, when it was inaugurated by ANDERSEN [70]. In this chapter, the beagle's respiratory characteristics are summarized and compared to those of the human and rat.

Mean values of selected lung function parameters are listed in table 1 [71]. Nasal, airway and acinar structures are each described below.

\section{Nose}

The structure of the canine nose is more complex than the human nose because of its olfactory function. The nasal turbinates (nasoturbinate, maxilloturbinate and ethmoturbinate), covered by mucosa, occupy the major portion of the nasal cavity. They are characterized by a complex folding and branching pattern. The structure of the canine and human nasal and oral cavities allows oronasal breathing. In contrast, most small laboratory animals are obliged to breathe nasally.

Table 1. - Lung function characteristics [71]

\begin{tabular}{lccc}
\hline & Beagle & Human & Rat \\
\hline Tidal volume $\mathrm{cm}^{3}$ & 193 & 500 & 1.4 \\
$f \mathrm{R}$ breaths $\cdot \mathrm{min}^{-1}$ & 19 & 12 & 115 \\
Minute volume $\mathrm{cm}^{3} \cdot \mathrm{min}^{-1}$ & 3700 & 6000 & 160 \\
Lung compliance $\mathrm{cm}^{3} \cdot \mathrm{Pa}^{-1}$ & 0.23 & 0.008 & 0.02 \\
Total lung capacity cm & 2.3 & 6 & 0.008 \\
\hline
\end{tabular}

$f_{R}$ : respiratory frequency.

\section{Lung}

Beagle lungs have seven lobes. The left lung is composed of cranial-middle and caudal lobes; the right lung of cranial, middle, caudal and accessory lobes. In comparison, human lungs have five lobes (left: upper and lower lobes; right: upper, middle and lower lobes) as do rat lungs (left lobe; right: cranial, middle, caudal and accessory lobes).

The comparative subgross anatomy of lungs is welldocumented [72-74]. Dog and rat lungs have a thin pleural wall and little, if any, interlobular connective tissue. In contrast, human lungs have a thick pleural wall and extensive interlobular connective tissues.

\section{Conducting airways}

Airway branching patterns are shown in figure 1 . This pattern is monopodial in beagle and rat lungs, but dichotomous in human lungs. Between the trachea and the most peripheral alveolus, canine lungs have 30 airway generations, whereas rat and human lungs have only 24 .

a)

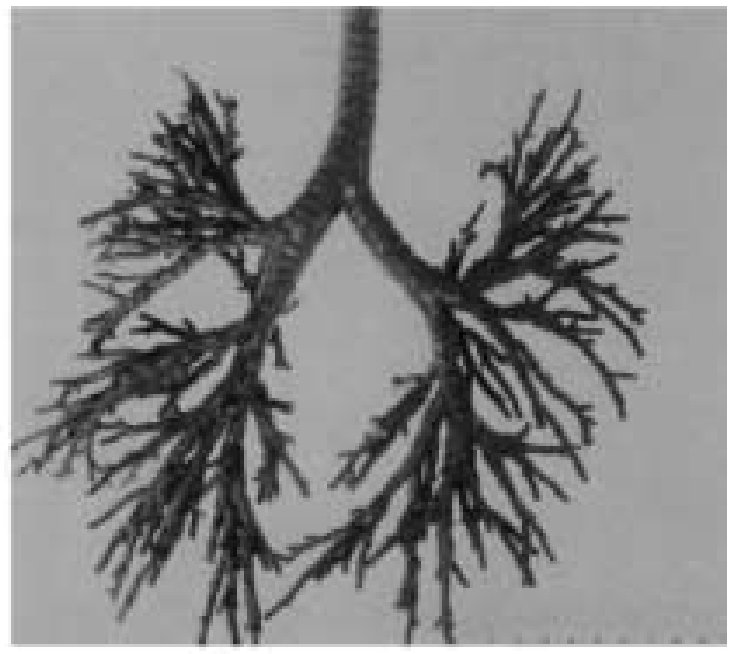

b)

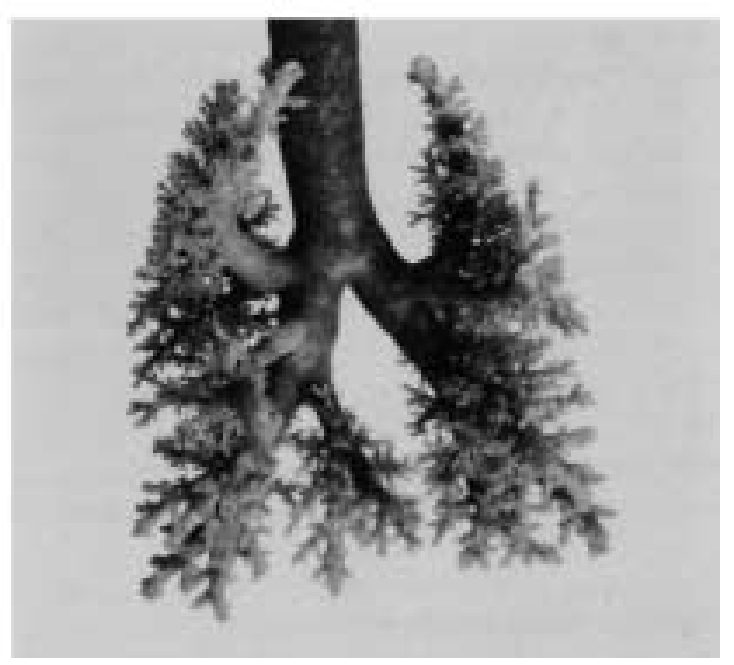

Fig. 1. - Tracheobronchial replica casts from: a) human lungs (courtesy of Dr Phalen); and b) beagle lungs (courtesy of Dr Schulz). 
Table 2. - Typical pathway lung models [75]

\begin{tabular}{|c|c|c|c|c|c|c|c|c|c|}
\hline \multirow[b]{2}{*}{$\begin{array}{l}\text { Generation } \\
\text { No. }\end{array}$} & \multicolumn{3}{|c|}{ Dog } & \multicolumn{3}{|c|}{ Human } & \multicolumn{3}{|c|}{ Rat } \\
\hline & $\begin{array}{c}\text { Tubes } \\
\mathrm{n}\end{array}$ & $\begin{array}{l}\text { Length } \\
\mathrm{cm}\end{array}$ & $\begin{array}{l}\text { Diameter } \\
\mathrm{cm}\end{array}$ & $\begin{array}{c}\text { Tubes } \\
n\end{array}$ & $\begin{array}{l}\text { Length } \\
\mathrm{cm}\end{array}$ & $\begin{array}{l}\text { Diameter } \\
\mathrm{cm}\end{array}$ & $\begin{array}{c}\text { Tubes } \\
n\end{array}$ & $\begin{array}{l}\text { Length } \\
\mathrm{cm}\end{array}$ & $\begin{array}{c}\text { Diameter } \\
\mathrm{cm}\end{array}$ \\
\hline 1 (trachea) & 1 & 14.8 & 1.8 & 1 & 10.0 & 2.01 & 1 & 2.680 & 0.340 \\
\hline 2 (main bronchus) & 2 & 1.38 & 1.49 & 2 & 4.36 & 1.56 & 2 & 0.715 & 0.290 \\
\hline 3 & 3 & 1.52 & 1.16 & 4 & 1.78 & 1.13 & 3 & 0.400 & 0.263 \\
\hline 4 & 5 & 0.989 & 0.879 & 8 & 0.965 & 0.827 & 5 & 0.176 & 0.203 \\
\hline 5 & 8 & 0.846 & 0.605 & 16 & 0.995 & 0.651 & 8 & 0.208 & 0.163 \\
\hline 6 & 13 & 0.547 & 0.472 & 32 & 1.01 & 0.574 & 14 & 0.117 & 0.134 \\
\hline 7 & 21 & 0.443 & 0.399 & 64 & 0.890 & 0.435 & 23 & 0.114 & 0.123 \\
\hline 8 & 35 & 0.370 & 0.377 & 128 & 0.962 & 0.373 & 38 & 0.130 & 0.112 \\
\hline 9 & 57 & 0.400 & 0.345 & 256 & 0.867 & 0.322 & 65 & 0.099 & 0.095 \\
\hline 10 & 95 & 0.320 & 0.329 & 512 & 0.667 & 0.257 & 109 & 0.091 & 0.087 \\
\hline 11 & 158 & 0.287 & 0.300 & 1024 & 0.556 & 0.198 & 184 & 0.096 & 0.078 \\
\hline 12 & 262 & 0.256 & 0.264 & 2048 & 0.446 & 0.156 & 309 & 0.073 & 0.070 \\
\hline 13 & 434 & 0.289 & 0.220 & 4096 & 0.358 & 0.118 & 521 & 0.075 & 0.058 \\
\hline 14 & 721 & 0.191 & 0.191 & 8192 & 0.275 & 0.092 & 877 & 0.060 & 0.049 \\
\hline 15 & 1195 & 0.162 & 0.176 & 16384 & 0.212 & 0.073 & 1477 & 0.055 & 0.036 \\
\hline 16 & 1983 & 0.159 & 0.141 & $\underline{32768}$ & 0.168 & $0.060 \mathrm{~A}$ & $\underline{2487}$ & 0.035 & $0.020 \mathrm{~A}$ \\
\hline 17 & 3290 & 0.134 & 0.114 & 65536 & 0.134 & 0.054 & 4974 & 0.029 & 0.017 \\
\hline 18 & 5458 & 0.124 & 0.092 & 131072 & 0.120 & 0.050 & 9948 & 0.025 & 0.016 \\
\hline 19 & 9054 & 0.103 & 0.074 & 262144 & 0.092 & 0.047 & 19896 & 0.022 & 0.015 \\
\hline 20 & 15019 & 0.094 & $0.052 \mathrm{~A}$ & 524288 & 0.080 & 0.045 & 39792 & 0.020 & 0.014 \\
\hline 21 & 30038 & 0.081 & 0.044 & 1048576 & 0.070 & 0.044 & 79584 & 0.019 & 0.014 \\
\hline 22 & 60076 & 0.071 & 0.036 & 2097152 & 0.063 & 0.044 & 159168 & 0.018 & 0.014 \\
\hline 23 & 120152 & 0.063 & 0.031 & 4194304 & 0.057 & 0.043 & 318336 & 0.017 & 0.014 \\
\hline 24 & 240304 & 0.055 & 0.027 & 8388608 & 0.053 & 0.043 & 636672 & 0.017 & 0.014 \\
\hline 25 & 480608 & 0.049 & 0.025 & $3 \times 10^{8}$ & 0.025 & 0.030 & $3 \times 10^{7}$ & 0.0072 & 0.0086 \\
\hline 26 & 961216 & 0.043 & 0.023 & & & & & & \\
\hline 27 & 1922432 & 0.038 & 0.022 & & & & & & \\
\hline 28 & 3844864 & 0.033 & 0.022 & & & & & & \\
\hline 29 & 7689728 & 0.029 & 0.021 & & & & & & \\
\hline 30 & 15379456 & 0.026 & 0.021 & & & & & & \\
\hline 31 & $8 \times 10^{8}$ & 0.0111 & 0.0133 & & & & & & \\
\hline
\end{tabular}

A: terminal bronchiole.

Typical pathway models of canine, human and rat lungs are listed in table 2 [75]. In the canine lung model, terminal bronchioles are represented by airway generation 20. However, morphological observations on lungs of six beagles (right caudal lobe) indicate that terminal bronchioles are actually associated with airway generation 25 [52].

Cell types, proliferation and differentiation in the mammalian airway epithelia are well-documented [76]. The density of cells differs among animal species and anatomical sites [77]. The cellular density in the bronchial tree of beagles (table 3 ) is similar to that of monkeys [16], and sheep [78]. Detailed data for human and rat lungs are not yet available.

The Clara cell becomes the major cell type in bronchioles. However, there are large differences among animal species in Clara cell morphology and distribution [79].

Submucosal glands are observed throughout the bronchial tree of beagles (table 4). In contrast to human and dog lungs, bronchial glands are not found in the lungs of small rodents. This interspecies variability is of great importance, since bronchial hyperplastic glands are typical indicators of chronic bronchitis.
Table 3. - Density of cellular components in the caudal lobe of the right beagle lung [52]

\begin{tabular}{lcc}
\hline & \multicolumn{2}{c}{ Airway generation } \\
\cline { 2 - 3 } & 5 & 20 \\
\hline Mucous goblet cell & $0.129 \pm 0.047$ & $0.181 \pm 0.028$ \\
Ciliated cell & $0.387 \pm 0.018$ & $0.385 \pm 0.033$ \\
Basal cell & $0.274 \pm 0.021$ & $0.282 \pm 0.025$ \\
Special type cell & $0.025 \pm 0.019$ & $0.024 \pm 0.013$ \\
Migratory cell & $0.017 \pm 0.017$ & $0.009 \pm 0.05$ \\
Small mucous granule cell & $0.169 \pm 0.034$ & $0.125 \pm 0.044$ \\
$\quad$ and undifferentiated cell & & \\
\hline
\end{tabular}

Values are presented as mean \pm SD.

Table 4. - Volume fraction of submucosal glands in the bronchial wall of beagles [52]

\begin{tabular}{cc}
\hline Airway generation & Volume fraction \\
\hline 5 & $0.024 \pm 0.009$ \\
10 & $0.040 \pm 0.003$ \\
15 & $0.057 \pm 0.002$ \\
20 & $0.038 \pm 0.003$ \\
\hline
\end{tabular}

Values are presented as mean \pm sD. 
Table 5. - Morphometric parameters of the acinar region [86]

\begin{tabular}{|c|c|c|c|}
\hline & Dog & Human & Rat \\
\hline $\begin{array}{l}\text { Tissue volume } \mathrm{cm}^{3} \\
\text { Epithelium }\end{array}$ & \multicolumn{2}{|c|}{ Epithelium } & 0.43 \\
\hline Type I cells & 16.5 & 32.5 & 0.08 \\
\hline Type II cells & 5.6 & 32.1 & 0.04 \\
\hline \multicolumn{4}{|l|}{ Interstitium } \\
\hline Cellular & 12.9 & 54 & 0.07 \\
\hline Noncellular & 22.8 & 98.3 & 0.13 \\
\hline Endothelium & 17.6 & 42.6 & 0.09 \\
\hline Macrophages & 2.5 & 54.7 & 0.02 \\
\hline \multicolumn{4}{|l|}{ Surface area $\mathrm{m}^{2}$} \\
\hline \multicolumn{4}{|l|}{ Epithelium } \\
\hline Type I cells & 51 & 89 & 0.39 \\
\hline Type II cells & 1 & 7 & 0.02 \\
\hline $\begin{array}{l}\text { Tissue thickness } \mu \mathrm{m} \\
\text { (harmonic mean) }\end{array}$ & 0.45 & 0.75 & 0.38 \\
\hline
\end{tabular}

\section{Acinus}

An acinus is composed of all airways distal to a terminal bronchiole and, thus, is served by a first-order respiratory bronchiole $[80,81]$. In the acinus of beagle lungs, several generations of alveolated bronchioles (i.e. respiratory bronchioles) are detected; human acini have similar morphology. However, the lungs of small rodents have either no respiratory bronchioles or, at most, one generation [80]. The average number of alveolar pores is similar in a canine and a human alveolus (7.2 vs 6.1 pores per alveolus), but smaller (1.3 pores) in a rat alveolus [82]. Since the acinar region is the main target site for many air pollutants, these interspecies differences in acinar morphology must be considered when comparing pulmonary responses to inhaled pollutants among species.

The structure of the acinar region of beagle lungs is well-documented [83-87]. Morphometric parameters of the acinar region beyond the respiratory bronchioles are listed in table 5 [86].

\section{Dosimetry of inhaled particles and gases}

Dosimetry refers to the mass of a pollutant that reaches specific target sites in the respiratory system. The dose received at these sites can be expressed as the mass of the pollutant per unit epithelium surface area (surface dose), or per unit volume element of lung tissue (volume dose). It depends upon the interaction between the inhaled pollutant and the liquid layer lining the specific site. In the case of particle exposure, all particles that hit this layer adhere to it. However, in the case of exposure to a pollutant gas, adherence of molecules depends on the solubility of the gas in the lining layer. Inhaled sulphur dioxide is rapidly taken up by airway surfaces, so the proximal airways have to be considered specific target sites. Inhaled ozone or nitrogen dioxide is less rapidly taken up in the lungs. Therefore, the centriacinar region (junctions between respiratory bronchioles and alveolar ducts) is the specific target site for these gases.
Dosimetric models for inhaled particles and gases are not yet available. Therefore, surrogate parameters are used to estimate the dose received by the respiratory system. Frequently, the concentration of particles and gases in the inspired air and the exposure time are the only surrogate parameters considered. When used alone, these parameters present a very incomplete picture of dose. More accurate dosimetry also requires data on minute ventilation and the uptake efficiency of particle or gas at the target site. However, these latter two parameters are difficult to measure experimentally. Thus, they must often be estimated from literature values, guessed at, or omitted entirely from consideration. It is, therefore, necessary that current research continues to focus on experimental and theoretical concepts for estimating the effective dose at specific target sites in the human lungs and the lungs of laboratory animals.

In terms of intrapulmonary deposition pattern of particles, the lungs of beagles and humans are reasonably alike. Although canine airways branch monopodially and human airways branch dichotomously, particle deposition is similar [88, 89]. For example, both in canines and humans, bronchial deposition for particles smaller than $2 \mu \mathrm{m}$ in diameter is rather low and increases with increasing particle size and with increasing penetration into the lungs, i.e. with increasing lung depth [90]. However, because the surface area of airways beyond the trachea increases rapidly with increasing lung depth, the surface dose of deposited particles declines correspondingly. Therefore, for accurate dosimetry, it must be recognized that despite the deposition of 0.5-5 um particles being lowest in proximal airways, the resulting surface dose in these airways is actually highest and then decreases towards the lung periphery. It must also be appreciated that this particle deposition pattern will be changed by disease. For instance, in chronic bronchitis, deposition in conducting airways is enhanced [91].

\section{Respiratory responses of canine lungs to inhaled ambient air pollutants}

Environmentally-controlled chambers are employed in long-term exposure studies with dogs. The technologies utilized in these types of studies were recently discussed [92]. Typical exposure systems use airflow that is continuous, horizontal, unidirectional, and has low-turbulent displacement. Pollutants are injected continuously into the airflow to ensure uniform whole-body exposure. The dogs are both housed and exposed in the chambers. An optimum design combines longitudinal studies (serial physiological, biochemical and cytological investigations on exposed and unexposed animals) with cross-sectional studies (postmortem morphological investigations on exposed and unexposed animals).

A few studies with high levels of sulphur dioxide were performed to induce chronic bronchitis. In these cases, dogs inhaled this gas through cuffed tracheostomy tubes at a concentration of 200 parts per million (ppm) for up to 18 months [17-19], or at a concentration of $50 \mathrm{ppm}$ for 11 months [20, 21]. 
Table 6. - Responses of the canine respiratory system to inhaled gaseous sulphur(IV) (sulphur dioxide) and particulate sulphur (IV) (neutral sulphite particles)

\begin{tabular}{|c|c|c|c|c|c|c|}
\hline \multirow{2}{*}{$\begin{array}{l}\text { Reference } \\
\text {. }\end{array}$} & \multirow[t]{2}{*}{ Animals } & \multicolumn{3}{|c|}{ Exposure } & \multicolumn{2}{|r|}{ Responses } \\
\hline & & Concentration & $\begin{array}{l}\text { Particle } \\
\text { size }\end{array}$ & $\begin{array}{l}\text { Total period } \\
\text { Weekly period } \\
\text { Daily period }\end{array}$ & Assessment & Symptoms, findings \\
\hline $\begin{array}{l}\text { LuLLING et al. } 1968 \text { [26] } \\
\text { (longitudinal study) }\end{array}$ & $\begin{array}{l}13 \text { male collies } \\
(6 \text { unexposed, } \\
7 \text { exposed })\end{array}$ & $\begin{array}{l}500 \mathrm{ppm} \mathrm{SO} \\
\left(660 \mathrm{mg} \mathrm{S}(\mathrm{IV}) \cdot \mathrm{m}^{-3}\right)\end{array}$ & & $\begin{array}{l}12 \text { months } \\
1-3 \text { days } \cdot \text { week }^{-1} \\
1-4 \text { h.day }{ }^{-1}\end{array}$ & $\begin{array}{l}\text { Physiology, } \\
\text { Morphology }\end{array}$ & $\begin{array}{l}\text { Cough, dyspnoea, } \\
\text { production of bronchial secretion } \\
\text { Increase in airway resistance } \\
\text { Hypertrophy of bronchial glands, } \\
\text { centriacinar emphysema }\end{array}$ \\
\hline $\begin{array}{l}\text { US EPA study I } \\
\text { LEWIs et al. } 1969 \text { [27] } \\
\text { LEWIs et al. } 1973 \text { [28] } \\
\text { (longitudinal study) }\end{array}$ & $\begin{array}{l}16 \text { female beagles } \\
\text { ( } 8 \text { unexposed, } \\
8 \text { exposed })\end{array}$ & $\begin{array}{l}5 \mathrm{ppm} \mathrm{SO} \\
\left(6.6 \mathrm{mg} \mathrm{S}(\mathrm{IV}) \cdot \mathrm{m}^{-3}\right)\end{array}$ & & $\begin{array}{l}21 \text { months } \\
7 \text { days } \cdot \text { week }^{-1} \\
21 \mathrm{~h}^{- \text {day }^{-1}}\end{array}$ & Physiology & $\begin{array}{l}\text { Increase in airway resistance, } \\
\text { decrease in pulmonary compliance }\end{array}$ \\
\hline $\begin{array}{l}\text { Philadelphia study } \\
\text { CHAKRIN \& SAUNDERS } 1974 \text { [34] } \\
\text { SPICER et al. } 1974 \text { [35] } \\
\text { LITT et al. } 1976 \text { [36] } \\
\text { (longitudinal study) }\end{array}$ & $\begin{array}{l}20 \text { male beagles } \\
(6 \text { unexposed, } \\
14 \text { exposed })\end{array}$ & $\begin{array}{l}550 \mathrm{ppm} \mathrm{SO}{ }_{2} \\
\left(720 \mathrm{mg} \mathrm{S}(\mathrm{IV}) \cdot \mathrm{m}^{-3}\right)\end{array}$ & & $\begin{array}{l}5 \text { months } \\
2 \text { days } \cdot \text { week }^{-1} \\
2 \mathrm{~h} \cdot \text { day }^{-1}\end{array}$ & $\begin{array}{l}\text { Rheology, } \\
\text { Morphology }\end{array}$ & $\begin{array}{l}\text { Excess of mucopurulent exudate } \\
\text { Biphasic response of viscoelastic properties } \\
\text { Increase in goblet cell number in small bronchi, } \\
\text { hyperplasia of bronchial glands }\end{array}$ \\
\hline $\begin{array}{l}\text { HIRSCH et al. } 1975 \text { [37] } \\
\text { (cross-sectional study) }\end{array}$ & $\begin{array}{l}12 \text { beagles } \\
(4 \text { unexposed, } \\
8 \text { exposed })\end{array}$ & $\begin{array}{l}1 \mathrm{ppm} \mathrm{SO}_{2} \\
\left(1.3 \mathrm{mg} \mathrm{S}(\mathrm{IV}) \cdot \mathrm{m}^{-3}\right)\end{array}$ & & $\begin{array}{l}12 \text { months } \\
5{\text { days} \cdot \text { week }^{-1}} \text { h.day }\end{array}$ & Clearance & Impairment of mucociliary activity \\
\hline $\begin{array}{l}\text { MALO et al. } 1983 \text { [41] } \\
\text { (longitudinal study) }\end{array}$ & $\begin{array}{l}5 \text { beagles, } \\
\text { both sexes } \\
(5 \text { exposed })\end{array}$ & $\begin{array}{l}500 \mathrm{ppm} \mathrm{SO}{ }_{2} \\
\left(660 \mathrm{mg} \mathrm{S}(\mathrm{IV}) \cdot \mathrm{m}^{-3}\right)\end{array}$ & & $\begin{array}{l}6 \text { months } \\
2 \text { days } \cdot \text { week }^{-1} \\
2 \mathrm{~h} \cdot \text { day }^{-1}\end{array}$ & Physiology & Increase in airway responsiveness \\
\hline $\begin{array}{l}\text { GREENE } \text { et al. } 1984 \text { [42] } \\
\text { (longitudinal study) }\end{array}$ & $\begin{array}{l}16 \text { beagles, } \\
\text { both sexes } \\
(4 \text { unexposed, } \\
12 \text { exposed })\end{array}$ & $\begin{array}{l}500 \mathrm{ppm} \mathrm{SO} \mathrm{SO}_{2} \\
\left(660 \mathrm{mg} \mathrm{S}(\mathrm{IV}) \cdot \mathrm{m}^{-3}\right)\end{array}$ & & $\begin{array}{l}5 \text { months } \\
5 \text { days } \cdot \text { week }^{-1} \\
2 \mathrm{~h} \cdot \text { day }^{-1}\end{array}$ & $\begin{array}{l}\text { Cytology } \\
\text { Clearance } \\
\text { Morphology }\end{array}$ & $\begin{array}{l}\text { Mucoid nasal discharge, cough } \\
\text { Persistent lung inflammation } \\
\text { Impairment of tracheal mucous velocity } \\
\text { Goblet cell hypertrophy, } \\
\text { hyperplasia of bronchial glands }\end{array}$ \\
\hline $\begin{array}{l}\text { GSF study I } \\
\text { HEYDER et al. } 1992 \text { [43] } \\
\text { MAIER et al. } 1992 \text { [44] } \\
\text { KREYLING et al. } 1992 \text { [45] } \\
\text { SCHULZ et al. } 1992 \text { [46] } \\
\text { TAKENAKA et al. } 1992 \text { [47] } \\
\text { (longitudinal study) }\end{array}$ & $\begin{array}{l}11 \text { male beagles } \\
\text { ( } 3 \text { unexposed, } \\
8 \text { exposed) }\end{array}$ & $\begin{array}{l}\left.1 \mathrm{mg} \mathrm{Na} \mathrm{SO}_{3} \cdot \mathrm{m}^{-3}\right) \\
0.07 \mathrm{ppm} \mathrm{SO} \\
\left(0.3 \mathrm{mg} \mathrm{S}(\mathrm{IV}) \cdot \mathrm{m}^{-3}\right)\end{array}$ & $0.6 \mu \mathrm{m}$ & $\begin{array}{l}10 \text { months } \\
7 \text { days}^{\cdot} \text { week }^{-1} \\
22.5 \mathrm{~h}^{- \text {day }^{-1}}\end{array}$ & $\begin{array}{l}\text { Clearance } \\
\text { Physiology } \\
\text { Morphology }\end{array}$ & $\begin{array}{l}\text { Increase in alveolar-capillary permeability, } \\
\text { decrease in formation of oxygen radicals, } \\
\text { reduction in phagocytic capacity, } \\
\text { lung inflammation } \\
\text { Enhancement of macrophage-mediated } \\
\text { particle transport } \\
\text { Decrease in lung compliance, } \\
\text { reduction in diffusion capacity } \\
\text { Hyperplastic changes in the nasal cavity, } \\
\text { enlargement of airspaces }\end{array}$ \\
\hline
\end{tabular}


Respiratory responses of canine lungs have been investigated for whole-body exposures to ozone, nitrogen oxides, S(IV) (i.e. sulphur dioxide and/or sulphite particles), acidic particles and motor vehicle exhaust. The corresponding canine exposure studies are listed and summarized in tables 6-10. They cover a wide range of exposure concentrations, exposure periods, and assessed respiratory responses. Most of the studies were performed with a single gaseous pollutant. Mixtures of pollutants have only been employed in four studies, in which several pollutants were given either simultaneously or successively.

Dogs were simultaneously exposed to $\mathrm{SO}_{2}$ and $\mathrm{H}_{2} \mathrm{SO}_{4}$ droplets in both EPA studies, to simulate atmospheric conditions in which part of the ambient $\mathrm{SO}_{2}$ is oxidized to $\mathrm{SO}_{3}$ that ultimately reacts with water to form $\mathrm{H}_{2} \mathrm{SO}_{4}$ droplets. This mixture may have constituted the 1952 London fog, and it was suggested as early as 1954 that "it is possible that $\mathrm{SO}_{2}$ dissolved as sulphuric acid in fog droplets appreciably reinforces the harmful effect of $\mathrm{SO}_{2}$ " [93]. Diluted exhaust from gasoline engines was used as the exposure atmosphere in the second EPA study.

The first GSF study attempted to simulate another ambient air pollution scenario. Ambient particles offer a huge surface area for interactions with $\mathrm{SO}_{2}$ that can lead to either the direct formation of particulate S(IV) as sulphites or to $\mathrm{SO}_{2}$ adsorption onto particles. Therefore, sulphite particles were used as surrogates for particleassociated S(IV). In the second GSF study, dogs were exposed to the sulphite particles in combination with acidic sodium bisulphate particles. Since it was recently recognized that the biologically active portions of acidic ambient compounds are $\mathrm{H}^{+}$ions [68], this exposure atmosphere may also resemble the pollution mixture of the 1952 London smog.

Although the database for long-term canine exposure studies is rather heterogeneous, there is sufficient coherence among the results to support the conclusions emerging from comparable studies with humans and small laboratory animals. In combination, the findings strengthen the proposition that prolonged exposure to high levels of air pollutants can cause irreversible lung injury and, ultimately, disease.

The studies also show that impaired lung function parameters indicative of parenchymal abnormalities (increased lung volumes; decreased compliance and diffusing capacity) correlate well with morphologically documented acinar airspace enlargement and, thus, emphysematous lesions. Furthermore, impaired lung function parameters indicative of airway abnormalities (increased airway resistance and decreased airway responsiveness) and

Table 7. - Responses of the canine respiratory system to inhaled nitrogen oxides

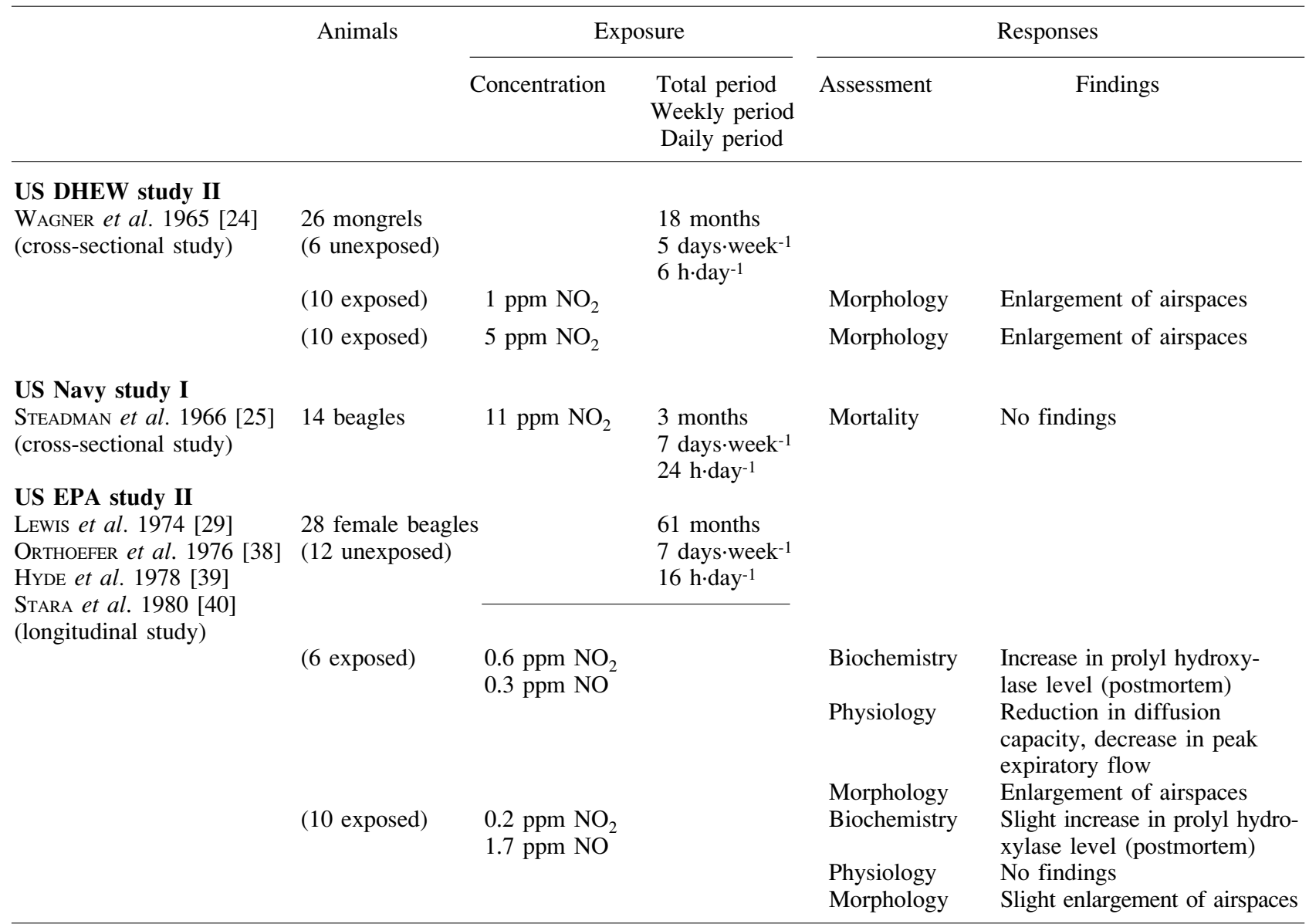

ppm: parts per million; DHEW: Department of Health, Education and Welfare (US); EPA: Environmental Protection Agency. 
Table 8. - Responses of the canine respiratory system to inhaled ozone

\begin{tabular}{|c|c|c|c|c|c|c|}
\hline & \multirow[t]{2}{*}{ Animals } & \multicolumn{2}{|c|}{ Exposure } & \multicolumn{3}{|c|}{ Responses } \\
\hline & & Concentration & $\begin{array}{l}\text { Total period } \\
\text { Weekly period } \\
\text { Daily period }\end{array}$ & Assessment & Findings & \\
\hline $\begin{array}{l}\text { US DHEW Study I } \\
\text { STOCKINGER et al. } 1957 \text { [23] } \\
\text { (cross-sectional study) }\end{array}$ & $\begin{array}{l}6 \text { unspecified dogs } \\
(2 \text { unexposed, } \\
4 \text { exposed })\end{array}$ & $1 \mathrm{ppm}$ ozone & $\begin{array}{rl}14 & \text { months } \\
5 & \text { days }^{-w_{e}} \mathrm{ek}^{-1} \\
6 & \mathrm{~h} \cdot \text { day }^{-1}\end{array}$ & Morphology & No findings & \\
\hline $\begin{array}{l}\text { US Navy study II } \\
\text { Jones et al. } 1970 \text { [31] } \\
\text { (cross-sectional study) }\end{array}$ & $\begin{array}{l}26 \text { male beagles } \\
(8 \text { unexposed, } \\
18 \text { exposed })\end{array}$ & $1.5 \mathrm{ppm}$ ozone & $\begin{aligned} 3 & \text { months } \\
7 & \text { days } \cdot \text { week }^{-1} \\
24 & \text { h.day- } 1\end{aligned}$ & $\begin{array}{l}\text { Mortality } \\
\text { Morphology }\end{array}$ & $\begin{array}{l}\text { No findings } \\
\text { Nonspecific inflammatory changes }\end{array}$ & \\
\hline \multirow{6}{*}{$\begin{array}{l}\text { US EPA study III } \\
\text { FREEMAN et al. } 1973 \text { [32] } \\
\text { STEPHENS et al. } 1973 \text { [33] } \\
\text { (cross-sectional study) }\end{array}$} & $\begin{array}{l}48 \text { female beagles } \\
\text { ( } 8 \text { unexposed) }\end{array}$ & & $\begin{aligned} 18 & \text { months } \\
7 & \text { days } \cdot \text { week }^{-1}\end{aligned}$ & & & \\
\hline & (8 exposed) & $1 \mathrm{ppm}$ ozone & 8 h.day ${ }^{-1}$ & Morphology & $\begin{array}{l}\text { Accumulation of alveolar macrophages, } \\
\text { deposition of fibrous elements }\end{array}$ & $\begin{array}{l}+1 \\
+1\end{array}$ \\
\hline & (8 exposed) & $1 \mathrm{ppm}$ ozone & $16 \mathrm{~h} \cdot \mathrm{day}^{-1}$ & Morphology & $\begin{array}{l}\text { Accumulation of alveolar macrophages, } \\
\text { deposition of fibrous elements }\end{array}$ & $\begin{array}{l}+2 \\
+2\end{array}$ \\
\hline & (8 exposed) & 1 ppm ozone & $24 \mathrm{~h} \cdot$ day $^{-1}$ & Morphology & $\begin{array}{l}\text { Accumulation of alveolar macrophages, } \\
\text { deposition of fibrous elements, } \\
\text { thickening of bronchiolar walls }\end{array}$ & $\begin{array}{l}+3 \\
+2 \\
+1\end{array}$ \\
\hline & (8 exposed) & $2 \mathrm{ppm}$ ozone & 8 h $\cdot$ day $^{-1}$ & Morphology & $\begin{array}{l}\text { Accumulation of alveolar macrophages, } \\
\text { deposition of fibrous elements, } \\
\text { thickening of bronchiolar walls, } \\
\text { squamous metaplasia }\end{array}$ & $\begin{array}{l}+3 \\
+3 \\
+2 \\
+1\end{array}$ \\
\hline & (8 exposed) & 3 ppm ozone & 8 h.day ${ }^{-1}$ & Morphology & $\begin{array}{l}\text { Accumulation of alveolar macrophages, } \\
\text { deposition of fibrous elements, } \\
\text { thickening of bronchiolar walls, } \\
\text { squamous metaplasia }\end{array}$ & $\begin{array}{l}+4 \\
+4 \\
+3 \\
+2\end{array}$ \\
\hline
\end{tabular}

For abbreviations see legend to table 7. 


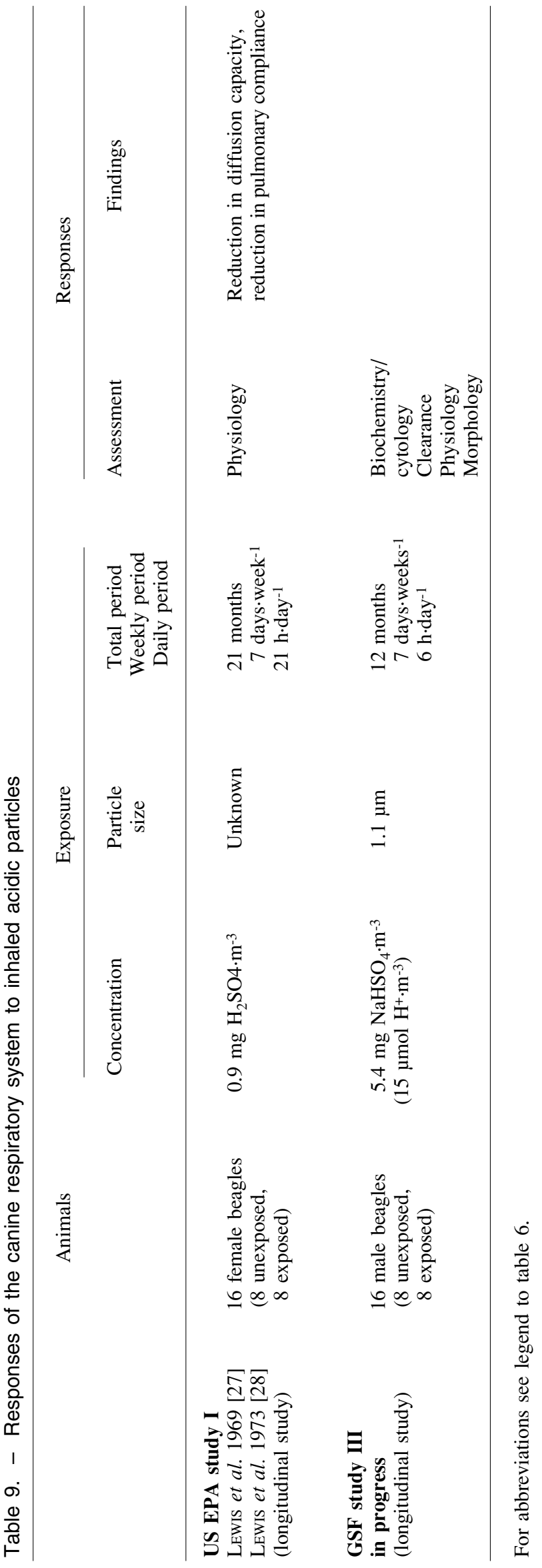

impaired mucociliary transport also correlate well with morphological observations (hypertrophy and hyperplasia of bronchial glands and nonciliated bronchiolar cells) and, thus, bronchitic lesions. In none of the studies was there an indication of allergic responses.

\section{$\operatorname{Sulphur}(I V)$}

Sulphur(IV), the IV-valent sulphur, is the reactive molecule in sulphur oxide moieties. In long-term canine studies (table 6), its concentration has been varied by more than three orders of magnitude $\left(0.3-720 \mathrm{mg} \cdot \mathrm{m}^{-3}\right)$. At high levels of exposure, an increased prevalence both of chronic bronchitis [26, 34-36, 41, 42] and emphysematous lesions has been observed [26]. At lower levels of exposure, respiratory responses were similar to those observed at high levels, but they occurred later. For instance, GREENE et al. [42] reported persistent lung inflammation during exposure to $660 \mathrm{mg} \cdot \mathrm{m}^{-3}$, whereas, at the lowest exposure level, an inflammatory response was detected only late in the study [44]. In this GSF study, no indication of chronic bronchitis was observed, but there were functional and morphometrical indications of the early stage of emphysema, which resulted from delivery of particulate S(IV) to the lung periphery.

The S(IV)-concentration required to cause responses in the canine lungs is lower than that required to cause the same response in rat lungs [9]. This difference can be due to either a lower dose received by the canine lungs or a higher susceptibility of canine lung tissue in comparison to rat lung tissue.

\section{Nitrogen oxides}

$\mathrm{NO}_{2}$-induced respiratory responses lead to emphysematous lesions in canine lungs (table 7). The findings of the second EPA study suggest that these lesions are dose-related, and nitrogen dioxide is a pneumotoxin of stronger potency than nitrogen oxide. The presence of fibrotic lesions is suggested by an increase in the intrapulmonary levels of prolyl hydroxylase, which is also dose-dependent.

\section{Ozone}

There are only limited data concerning long-term canine exposure studies with ozone (table 8 ). To estimate the effects of inhaled ozone on function and structure of the respiratory system, the only available studies are with small laboratory animals [22], or nonhuman primates [15]. With ozone exposures, it is worthwhile noting that a constant product of concentration $\times$ exposure time does not always produce the same findings. The morphological scores indicate that the intensity of the morphological lesions increases with increasing concentration; the exposure time is less important [32]. 
Table 10. - Responses of the canine respiratory system to mixtures of air pollutants

\begin{tabular}{|c|c|c|c|c|c|c|}
\hline & \multirow[t]{2}{*}{ Animals } & \multicolumn{3}{|c|}{ Exposure } & \multicolumn{2}{|r|}{ Responses } \\
\hline & & Concentration & $\begin{array}{l}\text { Particle } \\
\text { size }\end{array}$ & $\begin{array}{l}\text { Total period } \\
\text { Weekly period } \\
\text { Daily period }\end{array}$ & Assessment & Findings \\
\hline \multirow{5}{*}{$\begin{array}{l}\text { US EPA study II } \\
\text { LEWIS et al. } 1974 \text { [29] } \\
\text { ORTHOEFER et al. } 1976 \text { [38] } \\
\text { HYDE } \text { et al. } 1978 \text { [39] } \\
\text { STARA et al. } 1980[40] \\
\text { (longitudinal study) }\end{array}$} & $\begin{array}{l}47 \text { female beagles } \\
\text { (12 unexposed) }\end{array}$ & & & $\begin{array}{l}68 \text { months } \\
7 \text { days } \cdot \text { week }^{-1} \\
16 \text { h.day-1 }\end{array}$ & & \\
\hline & (10 exposed) & $\begin{array}{l}\text { Auto exhaust: } \\
98 \mathrm{ppm} \mathrm{CO} \\
28 \mathrm{ppm} \mathrm{HC} \\
0.05 \mathrm{ppm} \mathrm{NO}{ }_{2} \\
1.5 \mathrm{ppm} \mathrm{NO}\end{array}$ & & & $\begin{array}{l}\text { Biochemistry } \\
\text { Physiology } \\
\text { Morphology }\end{array}$ & $\begin{array}{l}\text { Slight increase in prolyl hydroxylase level } \\
\text { (postmortem) } \\
\text { Pulmonary hyperinflation } \\
\text { Hyperplasia of nonciliated bronchiolar cells }\end{array}$ \\
\hline & (5 exposed) & $\begin{array}{l}\text { Irradiated auto exhaust: } \\
95 \mathrm{ppm} \mathrm{CO} \\
24 \mathrm{ppm} \mathrm{HC} \\
1 \mathrm{ppm} \mathrm{NO} \mathrm{NO}_{2} \\
0.2 \mathrm{ppm} \mathrm{NO} \\
0.2 \mathrm{ppm} \text { ozone }\end{array}$ & & & $\begin{array}{l}\text { Biochemistry } \\
\text { Physiology } \\
\text { Morphology }\end{array}$ & $\begin{array}{l}\text { Increase in prolyl hydroxylase level } \\
\text { (postmortem) } \\
\text { Increase in airway resistance, } \\
\text { impairment in ventilatory distribution } \\
\text { Slight hyperplasia of nonciliated bronchiolar } \\
\text { cells }\end{array}$ \\
\hline & (9 exposed) & $\begin{array}{l}0.1 \mathrm{mg} \mathrm{H} \mathrm{H}_{2} \cdot \mathrm{SO}_{4}^{-3} \\
0.5 \mathrm{ppm} \mathrm{SO} \mathrm{S}_{2} \\
\text { auto exhaust }\end{array}$ & $0.5 \mu \mathrm{m}$ & & $\begin{array}{l}\text { Biochemistry } \\
\text { Physiology } \\
\text { Morphology }\end{array}$ & $\begin{array}{l}\text { Slight increase in prolyl hydroxylase level } \\
\text { (postmortem) } \\
\text { Pulmonary hyperinflation } \\
\text { Hyperplasia of nonciliated bronchiolar cells }\end{array}$ \\
\hline & (11 exposed) & $\begin{array}{l}0.1 \mathrm{mg} \mathrm{H} \mathrm{SO}_{4} \cdot \mathrm{m}^{-3} \\
0.4 \mathrm{ppm} \mathrm{SO} \mathrm{SO}_{2} \\
\text { irradiated auto exhaust }\end{array}$ & $0.5 \mu \mathrm{m}$ & & $\begin{array}{l}\text { Biochemistry } \\
\text { Physiology } \\
\text { Morphology }\end{array}$ & $\begin{array}{l}\text { Increase in prolyl hydroxylase level } \\
\text { (postmortem) } \\
\text { Increase in airway resistance } \\
\text { Enlargement of air spaces }\end{array}$ \\
\hline $\begin{array}{l}\text { US EPA study I } \\
\text { LewIS et al. } 1969 \text { [27] } \\
\text { LewIS et al. } 1973 \text { [28] } \\
\text { (longitudinal study) }\end{array}$ & $\begin{array}{l}16 \text { female beagles } \\
\text { ( } 8 \text { unexposed, } \\
8 \text { exposed) }\end{array}$ & $\begin{array}{l}0.9 \mathrm{mg} \mathrm{H} \mathrm{SO}_{4} \cdot \mathrm{m}^{-3} \\
5 \mathrm{ppm} \mathrm{SO} \\
\mathrm{pO}_{2}\end{array}$ & Unknown & $\begin{array}{l}21 \text { months } \\
7 \text { days }^{-w_{e}} e^{-1} \\
21 \mathrm{~h}^{-1} \text { day }^{-1}\end{array}$ & Physiology & $\begin{array}{l}\text { Reduction in diffusion capacity, } \\
\text { reduction in residual and total lung volume, } \\
\text { increase in airway resistance }\end{array}$ \\
\hline $\begin{array}{l}\text { US EPA study II } \\
\text { LEWIS et al. } 1974 \text { [29] } \\
\text { ORTHOEFER et al. } 1976 \text { [38] } \\
\text { HYDE } \text { et al. } 1978[39] \\
\text { STARA } \text { et al. } 1980[40] \\
\text { (longitudinal study) }\end{array}$ & $\begin{array}{l}20 \text { female beagles } \\
\text { (12 unexposed, } \\
8 \text { exposed })\end{array}$ & $\begin{array}{l}0.1 \mathrm{mg} \mathrm{H} \mathrm{SO}_{4} \cdot \mathrm{m}^{-3} \\
0.4 \mathrm{ppm} \mathrm{SO} \mathrm{SO}_{2}\end{array}$ & $0.5 \mu \mathrm{m}$ & $\begin{array}{l}68 \text { months } \\
7 \text { days } \cdot \text { week }^{-1} \\
16 \text { h.day- }{ }^{-1}\end{array}$ & $\begin{array}{l}\text { Biochemistry } \\
\text { Physiology } \\
\text { Morphology }\end{array}$ & $\begin{array}{l}\text { Slight increase in prolyl hydroxylase level } \\
\text { (postmortem) } \\
\text { No findings } \\
\text { Enlargement of airspaces }\end{array}$ \\
\hline
\end{tabular}




\section{Acidic particles}

The only long-term canine exposure study performed with acidic particles (table 9) offers little insight into respiratory responses caused by $\mathrm{H}^{+}$ions. One observation from physiological measurements is that these ions induce the lungs to produce bronchitic as well as emphysematous lesions.

\section{Mixtures of pollutants}

Under ambient conditions, people are always exposed to mixtures of pollutants. Therefore, controlled exposure studies with mixtures of pollutants (table 10) are closer to the "real world" than exposure studies using a single pollutant. However, it is controversial whether respiratory responses observed for single pollutants will be enhanced or reduced when these pollutants are inhaled as mixtures. Upon reviewing controlled human studies with air pollutants, SANDSTRÖM [53] concluded there is no potentiation of effects observed for pollutant mixtures in comparison to the separate constituents. In contrast, in a review of exposure studies with small laboratory animals, Chitano et al. [22] concluded that synergistic effects are indeed observed with mixtures of nitrogen dioxide and ozone or mixtures of nitrogen oxide or ozone with other pollutants. No indication of synergistic effects was found in the long-term canine studies. However, respiratory responses due to the inhalation of mixtures of nitrogen dioxide and ozone were not studied in dogs.

Thus, it may be that synergism only occurs with exposure mixtures involving nitrogen dioxide and/or ozone; not for mixtures with other constituents. Synergism could also be characteristic of only certain animal species or pollutant interactions in the lungs over long but not short periods of time. Finally and importantly is the location of specific target sites. The specific target site both for nitrogen dioxide and ozone is the centriacinar region. Therefore, the likelihood of interactions between respiratory responses of these pollutants is much higher than that between pollutants deposited at different target sites, such as sulphur dioxide and sulphuric acid droplets. It is not surprising that respiratory responses produced by sulphur dioxide and sulphuric acid droplets in canine lungs appear to be additive rather than synergistic.

After dogs were chronically exposed to the exhaust of petrol engines (auto exhaust), nonciliated bronchiolar (Clara) cells were affected and fibrotic lesions were observed. These changes could suggest the onset of small airway disease. However, it is remarkable that a reduction, rather than an enhancement, of lesions was observed when dogs were exposed to ultra violet (UV)-irradiated auto exhaust, since the UV-irradiation produced appreciable concentrations of ozone and nitrogen dioxide. When UV-irradiated exhaust was ultimately combined with gaseous and particulate S(IV) exposure, the hyperplasia of nonciliated bronchiolar (Clara) cells disappeared, but there was emphysematous airspace enlargement without alveolar fenestrae [94]. 
After cessation of exposure, the dogs of the second EPA study were kept under clean air conditions for 3 yrs before necropsy. No recovery of lesions occurred during this "recovery" period.

The most notable findings concerning pollutant mixtures were reported from the second GSF study. The response pattern observed in this study was entirely different from that observed in the first study. In the first GSF study, beagles were exposed to particle-associated $\mathrm{S}(\mathrm{IV})$ and in the second study additionally to particleassociated $\mathrm{H}^{+}$ions. Since the particle size distributions in both studies and for both pollutants, $\mathrm{S}(\mathrm{IV})$ and $\mathrm{H}^{+}$, were very similar, the specific target sites were the same. Nevertheless, most of the effects produced by the S(IV) particles disappeared when the dogs also inhaled particles carrying $\mathrm{H}^{+}$ions. Other effects also appeared, such as proliferation of type II cells and release of alkaline phosphatase by these cells. To fully understand these findings, a study is needed in which dogs are exposed solely to particle-associated $\mathrm{H}^{+}$ions. This study is in progress (table 9).

\section{Limitations of canine exposure studies}

In respiratory toxicology, there is a special need for investigations in humans, but such investigations are often impossible. Therefore, the only feasible way to address many air pollution questions is with laboratory animals. However, these animal studies must be undertaken with the caveat that extrapolation of findings from nonhuman observations to humans is subject to many sources of error, especially at unrealistically high exposure levels.

In addition to this general limitation, there are special considerations for long-term exposure studies with dogs. Firstly, ethical considerations, demanding labour requirements and high costs, limit studies to only a small number of animals. Secondly, the small sample size may require the use of sophisticated biostatistical techniques for analysis. Thirdly, dogs must be housed and exposed under conventional, hygienic conditions with frequent inspections to ensure that findings are not confounded by infectious diseases. Lastly, any spontaneously occurring functional and structural alterations must not be mistaken for exposure-related alterations, specifically fibrotic lesions in cranial lobes [47], or an increase in the number of eosinophils recoverable by bronchoalveolar lavage [95].

\section{Future aspects}

In epidemiological and controlled human exposure studies, susceptible populations have been identified, including infants, elderly individuals and individuals with underlying cardiopulmonary diseases. Healthy adults are considered to be much less, if at all, susceptible to inhaled pollutants at ambient levels. Nevertheless, most exposure studies with laboratory animals have been performed with healthy animals. Studies with animal models of cardiopulmonary diseases are, therefore, greatly needed.
Recently, it has been recognized that ambient particles might play a greater role in pollution-induced respiratory responses than previously thought [96-99]. Furthermore, fine or possibly ultrafine particles [100, 101] may be more toxic than coarse particles. The "physical" toxicity of these particles could even exceed their "chemical" toxicity. Therefore, it is beyond question, that there are tremendous research needs in the field of respiratory toxicology.

It must be re-emphasized that, in the "real world", humans are exposed to complex mixtures of ambient air pollutants, whereas most animal exposure studies have used only single pollutants. Therefore, long-term studies are needed with exposure atmospheres of increasing complexity. Eventually, it may be possible to simulate the complexity of the indoor and outdoor environment in controlled animal exposure studies, thereby enabling more relevant investigations of the interactions of pollutants in the lungs. Finally, it must be recognized that the roles of adaptation and tolerance have not been sufficiently addressed in air pollution exposure studies.

\begin{abstract}
Acknowledgement: The authors have pleasure in acknowledging J.D. Blanchard for competent editorial assistance.
\end{abstract}

\section{References}

1. Freeman G, Stephens RJ, Crane SC, Furiosi NJ. Lesion of the lung in rats continuously exposed to two parts per million of nitrogen dioxide. Arch Environ Health 1968; 17: 181-192.

2. Alarie Y, Ulrich CE, Busey WM, Swann HE, MacFarland $\mathrm{HN}$. Long-term continuous exposure of guinea-pigs to sulfur dioxide. Arch Environ Health 1970; 21: 769-777.

3. Alarie YC, Busey WM, Krumm AA, Ulrich CE. Longterm continuous exposure to sulfuric acid mist in Cynomolgus monkeys and guinea-pigs. Arch Environ Health 1973; 27: 16-24.

4. Alarie YC, Krumm AA, Busey WM, Ulrich CE, Kantz RJ. Long-term exposure to sulfur dioxide, sulfuric acid mist, fly ash, and their mixtures. Arch Environ Health 1975; 30: 254-262.

5. Juhos LT, Evans MJ, Mussenden-Harvey R, Furiosi NJ, Lapple CE, Freeman G. Limited exposure of rats to $\mathrm{H}_{2} \mathrm{SO}_{4}$ with and without $\mathrm{O}_{3}$. J Environ Sci Health 1978; C13: 33-48.

6. Moore PF, Schwarz LW. Morphological effects of prolonged exposure to ozone and sulfuric acid aerosol on the rat lung. Exp Mol Pathol 1981; 35: 108-123.

7. Ishinishi N, Koizumi A, McClellan RO, Stöber W, eds. Carcinogenic and mutagenic effects of diesel engine exhaust. Amsterdam, Elsevier, 1986.

8. Heinrich U, Muhle H, Takenaka S, et al. Chronic effects on the respiratory tract of hamsters, mice and rats after long-term inhalation of high concentration of filtered and unfiltered diesel engine emissions. J Appl Toxicol 1986; 6: 383-395.

9. Gunnison AF, Sellakumar A, Currie D, Snyder EA. Distribution, metabolism and toxicity of inhaled sulfur dioxide and endogenously generated sulfite in the respiratory tract of normal and sulfite oxidase-deficient rats. J Toxicol Environ Health 1987; 21: 141-162.

10. Kubota K, Murakami M, Takenaka S, Kawai K, Kyono 
H. Effects of long-term nitrogen dioxide exposure on rats lung: morphologic observations. Environ Health Perspect 1987; 73: 157-169.

11. Miller FJ, Graham JA, Raub JA, et al. Evaluating the toxicity of urban patterns of oxidant gases. II. Effects in mice from chronic exposure to nitrogen dioxide. $J$ Toxicol Environ Health 1987; 21: 99-112.

12. Lafuma C, Harf A, Lange F, Bozzi L, Poncy JL, Bignon J. Effect of low level $\mathrm{NO}_{2}$ chronic exposure on elastase-induced emphysema. Environ Res 1987; 43: 75-84.

13. Gearhart JM, Schlesinger RB. Response of the tracheobronchial mucociliary clearance system to repeated irritant exposure: effects of sulfuric acid mist on function and structure. Exp Lung Res 1988; 14: 587-605.

14. Alarie Y, Ulrich CE, Busey WM, Krumm AA, MacFarland HN. Long-term continuous exposure to sulfur dioxide in Cynomolgus monkeys. Arch Environ Health 1972; 24: 115-127.

15. Fujinaka LE, Hyde DM, Plopper CG, Tyler WS, Dungworth DL, Lollini LO. Respiratory bronchiolitis following long-term ozone exposure in bonnet monkeys: a morphometric study. Exp Lung Res 1985; 8: 167-190.

16. Plopper CG, Heidsiek J, Weir A, St George J, Hyde D. Tracheobronchial epithelium of the adult rhesus monkey: a quantitative histochemical and ultrastructural study. Am J Anat 1989; 184: 31-40.

17. Drazen JM, O'Cain CF, Ingram RH. Experimental induction of chronic bronchitis in dogs. Am Rev Respir Dis 1982; 126: 75-79.

18. Seltzer J, Scanlon PD, Drazen JM, Ingram RH Jr, Reid L. Morphologic correlation of physiologic changes caused by $\mathrm{SO}_{2}$-induced bronchitis in dogs: the role of inflammation. Am Rev Respir Dis 1984; 129: 790-797.

19. Shore SA, Kariya ST, Anderson K, et al. Sulfur dioxide-induced bronchitis in dogs: effects on airway responsiveness to inhaled and intravenously administered methacholine. Am Rev Respir Dis 1987; 135: 840-847.

20. Scanlon PD, Seltzer J, Ingram RH Jr, Reid L, Drazen JM. Chronic exposure to sulfur dioxide: physiologic and histologic evaluation of dogs exposed to 50 or $15 \mathrm{ppm}$. Am Rev Respir Dis 1987; 135: 831-839.

21. Bhaskar KR, Drazen JM, O'Sullivan DD, Scanlon PM, Reid LM. Transition from normal to hypersecretory bronchial mucus in a canine model of bronchitis: changes in yield and composition. Exp Lung Res 1988; 14: 101-120.

22. Chitano P, Hosselet JJ, Mapp CE, Fabbri LM. Effect of oxidant air pollutants on the respiratory system: insights from experimental animal research. Eur Respir J 1995; 8: $1357-1371$

23. Stokinger HE, Wagner WD, Dobrogorski OJ. Ozone toxicity studies. III. Chronic injury of lungs of animals following exposure at a low level. AMA Arch Ind Health 1957; 16: 514-522.

24. Wagner WD, Duncan BR, Wright PG, Stokinger HE. Experimental study of threshold limit of $\mathrm{NO}_{2}$. Arch Environ Health 1965; 10: 455-466.

25. Steadman BL, Jones RA, Rector DE, Siegel J. Effects on experimental animals of long-term continuous inhalation of nitrogen dioxide. Toxicol Appl Pharmacol 1966; 9: $160-170$.

26. Lulling J, Prignot J, Lievens P. Experimental bronchopneumopathy due to $\mathrm{SO}_{2}$ in the dog. Naunyn Sch Arch Pharmacol Exp Pathol 1968; 261: 1-25.

27. Lewis TR, Campbell KL, Vaughan TR. Effects on canine pulmonary function via induced $\mathrm{NO}_{2}$ impairment, particulate interaction and subsequent $\mathrm{SO}_{\mathrm{x}}$. Arch Environ Health 1969; 18: 596-601.
28. Lewis TR, Moorman WJ, Ludmann WF, Campbell KL. Toxicity of long-term exposure to oxides of sulfur. Arch Environ Health 1973; 26: 16-21.

29. Lewis TR, Moorman WJ, Yang YY, Stara JF. Longterm exposure to auto exhaust and other pollutant mixtures: effects on pulmonary function in the beagle. Arch Environ Health 1974; 29: 102-106.

30. Vaughan TR Jr, Jennelle LF, Lewis TR. Long-term exposure to low levels of air pollutants: effects on pulmonary function in the beagle. Arch Environ Health 1969; 19: 45-50.

31. Jones RA, Jenkins LJ Jr, Coon RA, Siegel J. Effects of long-term continuous inhalation of ozone on experimental animals. Toxicol Appl Pharmacol 1970; 17: 189-202.

32. Freeman G, Stephens RJ, Coffin DL, Stara JF. Changes in dogs' lung after long-term exposure to ozone: light and electron microscopy. Arch Environ Health 1973; 26: 209-216.

33. Stephens RJ, Freeman G, Stara JF, Coffin DL. Cytologic changes in dogs lungs induced by chronic exposure to ozone. Am J Pathol 1973; 73: 711-726.

34. Chakrin LW, Saunders LZ. Experimental chronic bronchitis: pathology in the dog. Lab Invest 1974; 30: 145154.

35. Spicer SS, Chakrin LW, Wardell JR Jr. Effect of chronic sulfur dioxide inhalation on the carbohydrate histochemistry and histology of the canine respiratory tract. Am Rev Respir Dis 1974; 110: 13-24.

36. Litt M, Khan MA, Chakrin LM, Sosnowski G, Wardell JR. Effect of chronic sulfur dioxide inhalation on rheological properties of tracheal mucus. Biorheol 1976; 13: $107-114$.

37. Hirsch JA, Swenson EW, Wanner A. Tracheal mucous transport in beagles after long-term exposure to $1 \mathrm{ppm}$ sulfur dioxide. Arch Environ Health 1975; 30: 249-253.

38. Orthoefer JG, Bhatnagar RS, Rahman A, Yang YY, Lee SD, Stara JF. Collagen and prolyl hydroxylase levels in lungs of beagles exposed to air pollutants. Environ Res 1976; 12: 299-305.

39. Hyde D, Orthoefer J, Dungworth D, Tyler W, Carter R, Lum H. Morphometric and morphologic evaluation of pulmonary lesions in beagle dogs chronically exposed to high ambient levels of air pollutants. Lab Invest 1978; 38: 455-469.

40. Stara JF, Dungworth D, Orthoefer JG, Tyler WS, eds. Long-term effects of air pollutants in canine species. Washington, DC, Report No. EPA-600/8-80-014, US Governmental Printing Office, 1980.

41. Malo PE, Wasserman MA, Griffin RL, Leong BKL, Powell DJ. Enhanced bronchoconstriction responses to prostaglandin $\mathrm{F}_{2 \alpha}$ following inhalation of sulfur dioxide. Prostaglandins 1983; 25: 179-192.

42. Greene SA, Wolff RK, Hahn FF, Henderson RF, Mauderly JL, Lundgren DL. Sulfur dioxide-induced chronic bronchitis in beagle dogs. J Toxicol Environ Health 1984; 13: 945-958.

43. Heyder J, Beck-Speier I, Ferron GA, et al. Early response of the canine respiratory tract following long-term exposure to a sulfur(IV) aerosol at low concentraion. I. Rationale, design, methodology and summary. Inhal Toxicol 1992; 4: 159-174.

44. Maier K, Beck-Speier I, Dayal N, et al. Early response of the canine respiratory tract following long-term exposure to a sulfur(IV) aerosol at low concentration. II. Biochemistry and cell biology of lung lavage fluid. Inhal Toxicol 1992; 4: 175-196.

45. Kreyling WG, Ferron GA, Fürst G, et al. Early response 
of the canine respiratory tract following long-term exposure to a sulfur(IV) aerosol at low concentration. III. Macrophage-mediated long-term particle clearance. Inhal Toxicol 1992; 4: 197-234.

46. Schulz H, Eder G, Heilmann P, et al. Early response of the canine respiratory tract following long-term exposure to a sulfur(IV) aerosol at low concentration. IV. Respiratory lung function. Inhal Toxicol 1992; 4: 235-246.

47. Takenaka S, Fürst G, Heilmann P, et al. Early response of the canine respiratory tract following long-term exposure to a sulfur(IV) aerosol at low concentration. V. Morphology and morphometry. Inhal Toxicol 1992; 4: 247-272.

48. Heyder J, Beck-Speier I, Dirscherl P, et al. Health effects of sulfur-related environmental air pollution: the role of acidic aerosols. Eur Respir J 1994; 7 (Suppl. 18): s214.

49. Maier K, Beck-Speier I, et al. Health effects of sulfurrelated environmental air pollution: the role of acidic aerosols on cellular and molecular parameters of injury. Inhal Toxicol (submitted).

50. Kreyling WG, Dirscherl P, Ferron GA, et al. Health effects of sulfur-related environmental air pollution: the role of acidic aerosols on unspecific defence mechanisms of the lung. Inhal Toxicol (submitted).

51. Schulz H, Ziesenis A, Meyer T, Eder G, Heyder J. Health effects of sulfur-related environmental air pollution: the role of acidic aerosols on respiratory lung function. Inhal Toxicol (submitted).

52. Takenaka S, Heini A, Karg E, Ritter B, Ziesenis, A, Heyder J. Health effects of sulfur-related environmental air pollution: proliferative changes in the proximal alveolar region in beagle dogs after long-term exposure to acidic sulfate and sulfite aerosols. Inhal Toxicol (submitted).

53. Sandström T. Respiratory effects of air pollutants: experimental studies in humans. Eur Respir J 1995; 8: 976995.

54. Lebowitz M. Epidemiology of air pollution. Eur Respir $J$ (in press).

55. Auerbach O, Hammond EC, Kirman D, Garfinke L, Stout AP. Histologic changes in bronchial tubes of cigarettesmoking dogs. Cancer 1967; 20: 2055-2066.

56. Hammond EC, Auerbach O, Kirman D, Garfinkel L. Effects of cigarette smoking on dogs. Arch Environ Health 1970; 21: 740-768.

57. Fraska JM, Auerbach O, Parks VR, Jaminson JD. Electron microscopic observations on pulmonary fibrosis and emphysema in smoking dogs. Exp Mol Pathol 1971; 15: 108-125.

58. Park SS, Kikkawa Y, Goldring IR, et al. An animal model of cigarette smoking in beagle dogs. Am Rev Respir Dis 1977; 115: 971-979.

59. Cross FT, Palmer RF, Filipy RE, Dagle GE, Stuart BO. Carcinogenic effects of radon daughters, uranium ore dust and cigarette smoke in beagle dogs. Health Phys 1982; 42: 33-52.

60. Stuart BO. Health assessment of environmental pollutants: proliferative and degenerative diseases. Toxicol Ind Health 1988; 4: 461-467.

61. Hahn FF. Chronic inhalation bioassays for respiratory tract carcinogenesis. In: Gardner DE, et al., eds. Toxicology of the Lung. New York, Raven Press, 1993; pp. 435-459.

62. United States Environmental Protection Agency. Air quality criteria for particulate matter and sulfur oxides. Washington, DC, Report No. EPA-600/8-82-029a, US Governmental Printing Office, 1982.

63. United States Environmental Protection Agency. Air quality criteria for ozone and other photochemical oxidants. Washington, DC, Report No. EPA-600/8-84020aF, US Governmental Printing Office, 1986.

64. United States Environmental Protection Agency. An acid aerosols issue paper: health effects and aerometrics. Washington, DC, Report No. EPA-600/8-88-005F, US Government Printing Office, 1989.

65. Department of Health. Advisory group on the medical aspects of air pollution episodes (Chairman: Holgate S). First Report: Ozone. London, HMSO, 1991.

66. Department of Health. Advisory group on the medical aspects of air pollution episodes (Chairman: Holgate S). Second Report: Sulphur dioxide, acid aerosols and particulates. London, HMSO, 1992.

67. World Health Organization. Air quality guideline for Europe. Copenhagen, WHO Regional Publications, 1987. European series: 23, 1987.

68. American Thoracic Society. Workshop Report. Health effects of atmospheric acids and their precursors. Am Rev Respir Dis 1991; 144: 464-467.

69. Brunekreef B, Dockery DW, Krzyzanowski M. Epidemiologic studies on short-term effects of low levels of major ambient air pollution components. Environ Health Perspect 1995; 103 (Suppl. 2): 3-13.

70. Andersen AC. The beagle as an experimental dog. Ames, Iowa, Iowa States University Press, 1970.

71. Phalen RF. Inhalation studies: foundations and techniques. Boca Raton, CRC Press, 1984.

72. McLaughlin RF Jr, Tyler WS, Canada RO. A study of the subgross pulmonary anatomy in various mammals. Am J Anat 1961; 108: 149-165.

73. McLaughlin RF Jr, Tyler WS, Canada RO. Subgross pulmonary anatomy of the rabbit, rat and guinea-pig, with additional notes on the human lung. Am Rev Respir Dis 1966; 94: 380-387.

74. Tyler WS. Small airways and terminal units: comparative subgross anatomy of lungs. Am Rev Respir Dis 1983; 128: s32-s36.

75. Yeh H-C, Harkema JR. Gross morphometry of airways. In: Gardner DE, et al., eds. Toxicology of the Lung. New York, Raven Press, 1993; pp. 55-79.

76. Ayers MN, Jeffery PK. Proliferation and differentiation in mammalian airway epithelium. Eur Respir J 1988; 1: $58-80$.

77. Hyde DM, Plopper CG, St George JA, Harkema JR. Morphometric cell biology of air space epithelium. In: Lenfant C, ed. Electron Microscopy of the Lung. New York, Marcel Dekker, 1990; pp. 71-120.

78. Mariassy AT, Plopper CG. Tracheobronchial epithelium of the sheep. I. Quantitative light microscopic study of epithelial cell abundance and distribution. Anat Rec 1983; 205: 263-275.

79. Plopper CG. Comparative morphologic features of bronchiolar epithelial cells: the Clara cell. Am Rev Respir Dis 1983; 128: s37-s41.

80. Rodriguez M, Bur S, Favre A, Weibel ER. Pulmonary acinus: geometry and morphometry of the peripheral airway system in rat and rabbit. Am J Anat 1987; 180: 143-155.

81. Haefeli-Bleuer B, Weibel ER. Morphometry of the human pulmonary acinus. Anat Rec 1988; 220: 401-414.

82. Port CD, Ketels KV, Coffin DL, Kane P. A comparative study of experimental and spontaneous emphysema. J Toxicol Environ Health 1977; 2: 589-604.

83. Siegwart B, Gehr P, Gill J, Weibel ER. Morphometric estimation of pulmonary diffusion capacity. IV. The normal dog lung. Respir Physiol 1971; 13: 141-159. 
84. Gehr P, Siegwart B, Weibel ER. Allometric analysis of the morphometric pulmonary diffusing capacity in dogs. J Morphol 1981; 16: 5-15.

85. Crapo RO, Crapo JD, Morris AH. Lung tissue and capillary blood volumes by rebreathing and morphometric techniques. Respir Physiol 1982; 49: 175-186.

86. Crapo JD, Young SL, Fram EK, Pinkerton KE, Barry $\mathrm{BE}$, Crapo RO. Morphometric characteristics of cells in the alveolar region of mammalian lungs. Am Rev Respir Dis 1983; 128: s42-s46.

87. Weibel ER, Taylor CR, O'Neil JJ, et al. Maximal oxygen consumption and pulmonary diffusing capacity: a direct comparison of physiologic and morphometric measurements in canids. Respir Physiol 1983; 54: 173-188.

88. Cuddihy RG, Brownstein DG, Raabe OG, Kanapilly GM. Respiratory tract deposition of inhaled polydisperse aerosols in beagle dogs. J Aerosol Sci 1973; 4: 35-45.

89. Kreyling WG, Eder K, Erbe F, et al. Particle deposition in the canine respiratory tract. Ann Occup Hyg 1994; 38 (Suppl. 1): 143-149.

90. Schulz H, Schulz A, Heyder J. Influence of intrinsic particle properties on the assessment of convective gas transport by aerosol bolus technique. Exp Lung Res (in press)

91. Greene SA, Lundgren DL, Snipes MB, Wolff RK. Deposition and clearance of particles inhaled by beagle dogs previously exposed to $\mathrm{SO}_{2}$. Exp Lung Res 1987; 13: 417-425.

92. Karg E, Tuch T, Erbe F, Ferron GA, et al. Design, operation and performance of whole body chambers for longterm aerosol exposure of large experimental animals. $J$ Aerosol Sci 1992; 23: 279-290.
93. Her Majesty's Stationary Office (HMSO). Mortality and morbidity during the London fog of December 1952. Report No. 95 on Public Health and Medical Subjects. London, HMSO, 1954.

94. Boren HG. Alveolar fenestrae: relationship to the pathology and pathogenesis of pulmonary emphysema. Am Rev Respir Dis 1962; 85: 328-344.

95. Beck-Speier I, Matejkova E, Heilmann P, Luippold GB, Dayal N, Maier K. An alveolar macrophage-stimulating activity in the bronchoalveolar lavage fluid of dogs with high eosinophil counts. Eur Respir J 1992, 5 (Suppl. 15): $126 \mathrm{~s}$.

96. Utell MJ, Samet JM. Particulate air pollution and health: new evidence on the old problem. Am Rev Respir Dis 1992; 147: 1334-1335.

97. Dockery DW, Pope CA, Xu X, et al. An association between air pollution and mortality in six US cities. $N$ Engl J Med 1993; 329: 1753-1759.

98. Pope CA, Bates DV, Roizerra MG. Health effects of particulate air pollution: time for reassessment? Environ Health Persp 1995; 103: 472-480.

99. Pope CA, Dockery DW, Schwartz J. Review of epidemiological evidence of health effects of particulate air pollution. Inhal Toxicol 1995; 7: 1-18.

100. Seaton A, MacNee W, Donaldson K, Godden D. Particulate air pollution and acute health effects. Lancet 1995; 345: 176-178.

101. Oberdörster G, Gelein RM, Ferin J, Weiss B. Association of particulate air pollution and acute mortality: involvement of ultrafine particles? Inhal Toxicol 1995; 7: 111-124. 